\title{
Oestrogenic effects of neonatal administration of raloxifene on hypothalamic-pituitary-gonadal axis in male and female rats
}

\author{
L. Pinilla, L. C. González, F. Gaytán, M. Tena-Sempere \\ and E. Aguilar \\ Department of Physiology, Faculty of Medicine, University of Córdoba, \\ Avda. Menéndez Pidal s/n, 14004 Córdoba, Spain
}

Selective oestrogen receptor modulators constitute a family of drugs that are used increasingly in the management of oestrogen-associated pathology. Raloxifene is a selective oestrogen receptor modulator that is used to treat and prevent osteoporosis in post-menopausal women. The actions of raloxifene on bone, breast, uterus and serum cholesterol concentrations have been widely analysed, but very few studies have investigated the possible actions of this drug on the central nervous system. The central nervous system of the newborn rat is very sensitive to oestrogen action. In this study a series of experiments was conducted to analyse the effects of different doses of raloxifene $(50,100,250$ or $500 \mu \mathrm{g}$ per rat per day) administered to neonatal rats on days 1-5 of age. Female rats treated with raloxifene showed decreased gonadotrophin secretion, hyperprolactinaemia, advanced vaginal opening, decreased body weight, persistent presence of cornified epithelial cells in vaginal smears, anovulation, inhibition of positive feedback between oestradiol and $\mathrm{LH}$, and infertility. Male rats showed delayed balanopreputial separation, reduced body weight and hyperprolactinaemia. All these changes resemble those obtained after neonatal administration of oestradiol benzoate, thus indicating, for the first time, that raloxifene exerts an oestrogenic action on the hypothalamic-pituitary structures controlling reproductive function in rats.

\section{Introduction}

The major target tissues of oestrogens are the mammary gland, the reproductive tract, bone, the cardiovascular system and the central nervous system (Clark et al., 1992; Turner et al., 1994; Ciocca and Vargas Roig, 1995; Farhat et al., 1996). In the rodent central nervous system, steroid input on hypothalamic neurones immediately after birth is critical for the organization of neural mechanisms involved in the control of neuroendocrine function, especially those serving reproductive activity (Whalen and Edward, 1969; Jacobson et al., 1981; Johnson and Gay, 1983; JeanFaucher et al., 1985; Jansson and Frohman, 1987; PozzoMiller and Aoki, 1991; Wall and Meyerson, 1997). Administration of testosterone propionate or oestradiol benzoate to female rats induced the persistent presence of cornified cells in vaginal smears with anovulation and hyperprolactinaemia (Barraclough, 1961; Gorski, 1963; Mallampatti and Johnson, 1973; Aguilar et al., 1979; Pinilla et al., 1993). In addition, administration of oestradiol to male rats permanently damaged Sertoli and germ cells and the function of Leydig cells (Dhar and Setty, 1976; Gaytan et al., 1986a,b; Gaytan and Aguilar, 1987). Since testosterone is converted into oestradiol in the central nervous system, it has been proposed that the oestrogenic

Email: fi1agbee@lucano.uco.es input on hypothalamic neurones determines the organization of the neural mechanisms involved in reproductive activity (Harlan et al., 1979; Goy and McEwen, 1980; Gorski, 1990).

Raloxifene is a non-steroidal selective oestrogen receptor modulator developed as a therapeutic agent for menopausal osteoporosis (Fuchs-Young et al., 1995). This drug blocks the effects of oestrogen in some tissues, such as the breast, whereas it mimics oestrogen action on bone and blood lipid concentrations (Wakeling et al., 1984; Glasebrook et al., 1993; Black et al., 1994; Yang et al., 1996; Delmas et al., 1997). At present, the effects of raloxifene on the neural circuitry controlling neuroendocrine function have not been evaluated extensively. In ovariectomized rats treated with oestradiol, raloxifene inhibited the decrease in serum $\mathrm{LH}$ concentrations and antagonized the increase in pituitary mass and mammary gland growth (Buelke-Sam et al., 1998). In addition, raloxifene antagonized the effects of oestrogen on different anterior pituitary hormones such as prolactin, LH and FSH (Draper et al., 1995). In contrast, administration of a single dose of raloxifene stimulated prolactin secretion and inhibited the release of FSH (Neubauer et al., 1993).

Despite the proven role of oestrogens as organizing agents of brain structures related to the neuroendocrine control of reproductive function, little attention has been given to the potential effect of raloxifene during the critical period of hypothalamic development in rodents. Raloxifene administered to pregnant rats from day 6 of gestation to day 20 post partum induced different alterations in offspring, such 
as advanced vaginal opening and interruption of vaginal cycles at 10 or 14 weeks of age (Buelke-Sam et al., 1998).

In the present study, experiments were designed to characterize the short- and long-term effects of neonatal administration of raloxifene in male and female rats, and special attention was given to its organizing effects of neural mechanisms involved in the control of neuroendocrine function, especially those serving reproductive activity.

\section{Materials and Methods}

\section{Animals and treatments}

Wistar rats born in our laboratory were kept under controlled conditions of light (12 h light:12 h dark, lights on at 07:00 h) and temperature $\left(22^{\circ} \mathrm{C}\right)$, and had free access to pelleted food (Pacsa Sanders, Seville) and tap water. The day the litters were born was considered as day 1 . At this stage, the litter size was adjusted to eight animals. These animals were weaned on day 21 and housed in groups of four to five animals per cage. Raloxifene chlorhydrate [2-(4-hydroxyphenyl)-6-hydroxybenzob-thien-3-yl-[4-[2-(1-piperidinyl)ethoxy-phenyl-methanone hydrochloride] (Evista ${ }^{\circledR}$, Lilly) was dissolved in saline and injected in a volume of $0.1 \mathrm{ml}$. All offspring from the same mother received the same treatment, and were pooled with pair-aged pups to be used randomly in different experiments.

\section{Experimental designs}

Females. The initial set of experiments analysed the effects of neonatal administration of raloxifene on the reproductive activity in female rats. In Expt 1, female rats (ten per group) were injected i.p. with raloxifene (50, 100, 250 or $500 \mu \mathrm{g}$ per rat per day) or vehicle on days 1-5 of age. Animals were weighed each day. Trunk blood was collected after decapitation on day 20 and the ovaries were removed and weighed. In Expt 2, female rats (ten per group) were injected i.p. with raloxifene (100, 250 or $500 \mu \mathrm{g}$ per rat per day) or vehicle on days $1-5$ of age. The age and body weight at vaginal opening were recorded. After vaginal opening, vaginal smears were taken each day. The appearance of cornified cells followed by 1-2 days of dioestrus was considered as the first oestrus. Blood samples were collected after light ether anaesthesia at vaginal opening and first oestrus. In Expt 3, female rats (ten per group) were injected i.p. with raloxifene (50, 100, 250 or $500 \mu \mathrm{g}$ per rat per day) or vehicle on days $1-5$ of age. After vaginal opening, vaginal smears were taken each day. The appearance of epithelial cornified cells on $>12$ consecutive days was considered as constant vaginal oestrus. Animals were killed at day 90 (control animals in the dioestrous phase) and trunk blood, ovaries and uteri were collected. In Expt 4, female rats (10-12 per group) were injected i.p. with raloxifene (50 or $100 \mu \mathrm{g}$ per rat per day) or vehicle on days 1-5 of age. The animals were ovariectomized on day 90, and 14 days later were injected i.p. with $75 \mu \mathrm{g}$ oestradiol benzoate. Blood samples were obtained by jugular vene- puncture after light ether anaesthesia before ovariectomy and on days 14 (at 10:00 h), 15 and 16 after ovariectomy (at 10:00 and 18:00 h). In Expt 5, female rats (10-12 per group) injected i.p. with raloxifene (250 or $500 \mu \mathrm{g}$ per rat per day) or vehicle on days $1-5$ of age were paired in adulthood with control adult males of proven fertility for 21 days, and examined for a further 21 days after separation from males. The percentage of pregnancies was recorded by physical examination and final delivery of pups.

Males. In Expt 6, male rats (ten per group) were injected i.p. with raloxifene $(50,100,250$ or $500 \mu$ g per rat per day) or vehicle on days $1-5$ of age. Trunk blood was collected after decapitation on day 20. Testes were removed and weighed. In Expt 7, male rats (ten animals per group) were injected i.p. with raloxifene (250 or $500 \mu \mathrm{g}$ per rat per day) or vehicle on days 1-5 of age. The age and body weight at balanopreputial separation were recorded. Blood samples were obtained after light ether anaesthesia on the same day. In Expt 8, male rats (ten per group) injected i.p. with raloxifene (250 or $500 \mu$ g per rat per day) or vehicle on days 1-5 of age were maintained until adulthood (day 90) and subsequently killed. Trunk blood, testes and ventral prostate were collected. In Expt 9, male rats (15 per group) were injected i.p. with raloxifene (250 or $500 \mu \mathrm{g}$ per kg per day) or vehicle on days 1-5 of age. In adulthood, the animals were paired with cyclic females for 21 days and the percentage of pregnancies was recorded as in Expt 5.

All experiments were approved by the Córdoba University Ethical Committee for animal experimentation and were conducted in accordance with the European Union regulations governing the care and use of experimental animals.

\section{Histological processing}

The testes and ovaries were fixed with Bouin-Hollande's fluid and processed by standard means. Section were cut at $5 \mu \mathrm{m}$ and stained with haematoxylin and eosin.

\section{Hormone assays}

Concentrations of LH, FSH and prolactin were measured by specific radioimmunoassays using kits supplied by the NIDDK (Bethesda, MD), and hormone concentrations were expressed using LH-RP-3, FSH-RP-2 and prolactin-RP-3 as standards. All samples were measured in duplicate and all samples from each experiment were measured in the same assay. Intra-assay coefficients of variation were $<8 \%$, and the sensitivities of the assays were 20.0, 7.5 and 10.0 pg per tube for $\mathrm{LH}, \mathrm{FSH}$ and prolactin, respectively.

\section{Statistical analysis}

Data are expressed as means \pm SEM. Chi-squared evaluation was used selectively for comparing data on fertility and the percentage of anovulatory cycles. All other data were analysed by one- or two-way ANOVA followed by Tukey's test. 


\section{Results}

Effects of neonatal administration of raloxifene on reproductive function in females

Expt 1. Female rats injected with raloxifene (250 or $500 \mu \mathrm{g} \mathrm{day}^{-1}$ ) showed a decrease in body weight, which was significant from day 12 of age onwards (Fig. 1a). On day 20 , such a decrease was also significant in groups treated with lower doses of raloxifene (50 and $100 \mu$ day $^{-1}$ ) (Fig. 1b). For all doses tested, raloxifene-treated females showed a significant reduction in ovarian mass (Fig. 2a) and serum LH and FSH concentrations on day 20 (Fig. 2b,c). In contrast, serum concentrations of prolactin increased (Fig. 2d).

Expt 2. Vaginal opening was advanced in female rats treated neonatally with raloxifene $(100,250$ and $500 \mu \mathrm{g}$
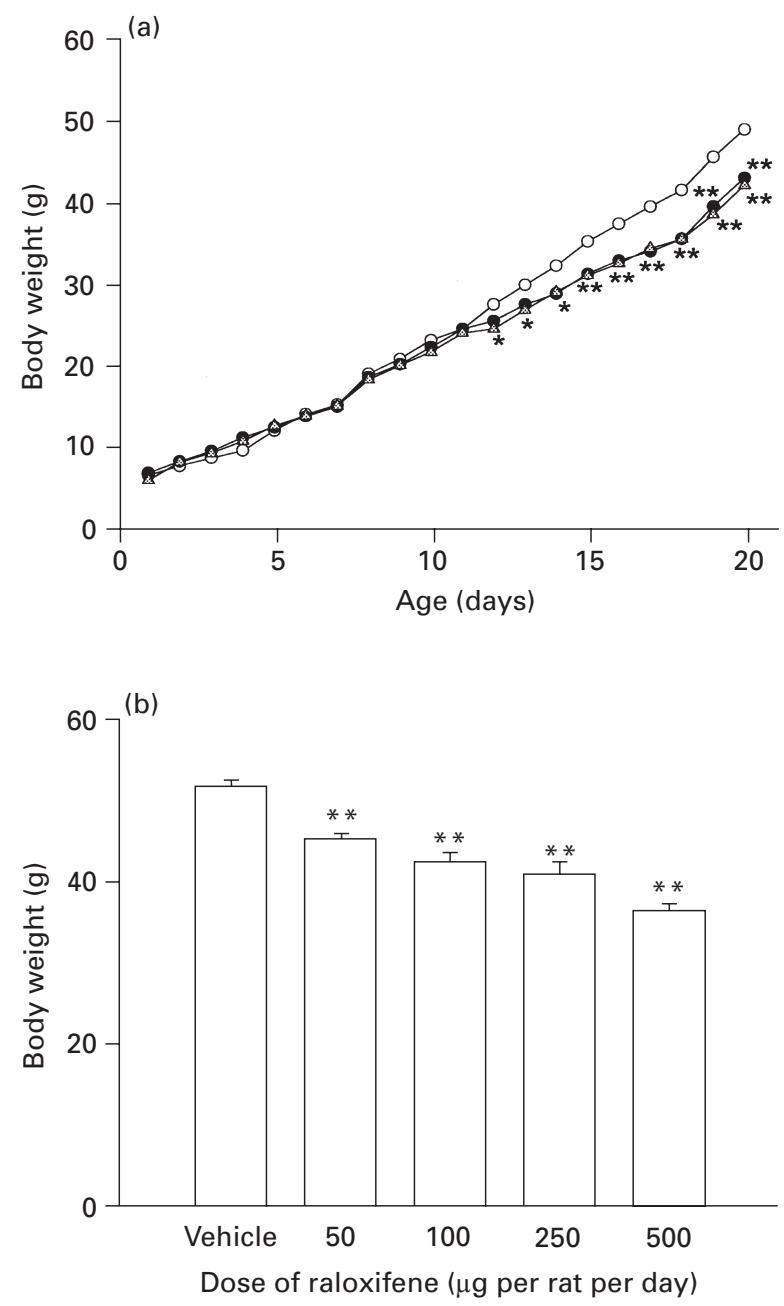

Fig. 1. (a) Changes in body weight ( $g$ ) in female rats treated with raloxifene $(250(\bullet)$ or $500(\triangle) \mu$ g per rat per day) or vehicle $(\bigcirc)$ on days 1-5 of age. (b) Body weight (g) in 20-day-old female rats treated with raloxifene $(50,100,250$ or $500 \mu \mathrm{g}$ per rat per day) on days $1-5$ of age. Data are expressed as means \pm SEM (ten animals per group). ${ }^{*} P \leqslant 0.05$ and ${ }^{* *} P \leqslant 0.01$ versus vehicle-treated rats (ANOVA followed by Tukey's test).
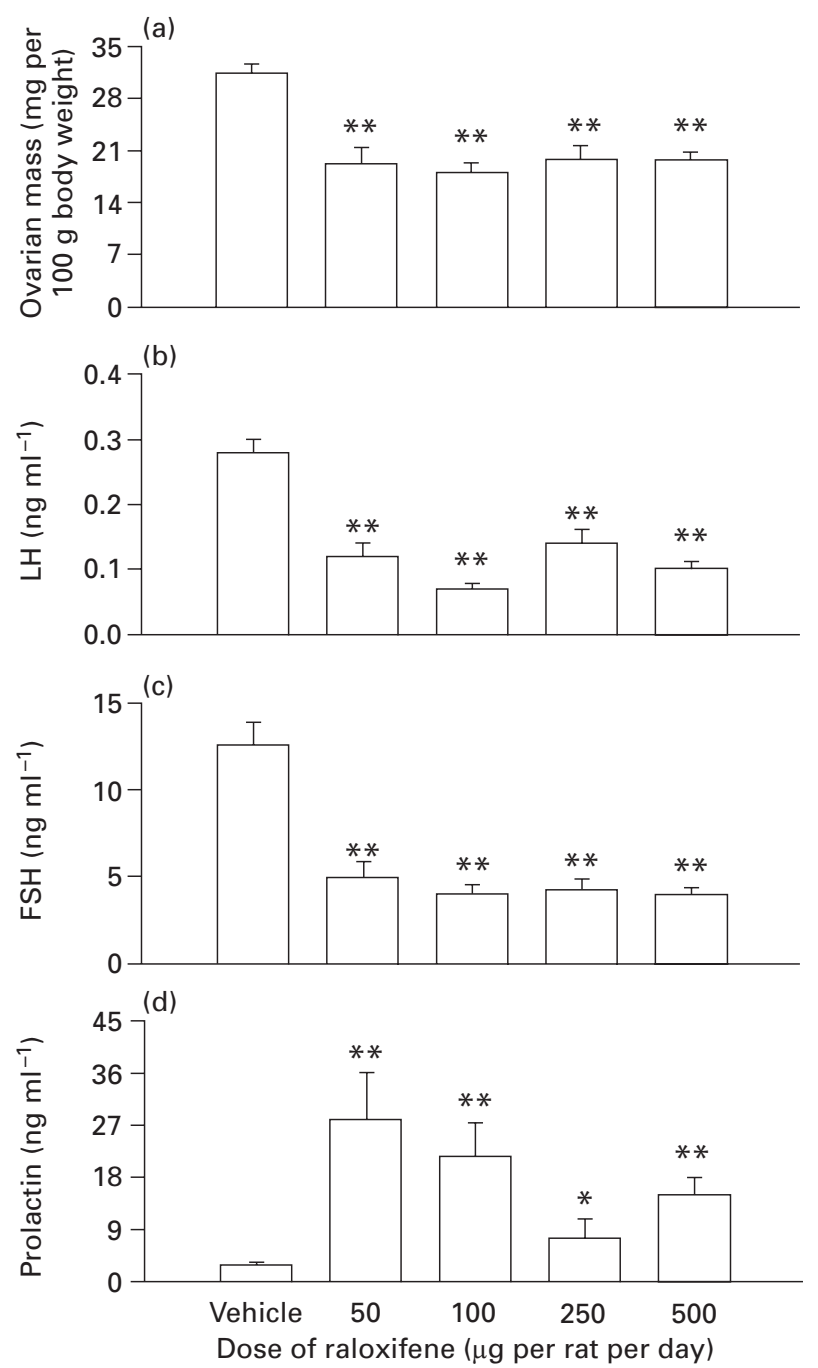

Fig. 2. Ovarian mass (a) and serum concentrations of LH (b), FSH (c) and prolactin (d) in 20-day-old female rats treated with raloxifene $(50,100,250$ or $500 \mu \mathrm{g}$ per rat per day) or vehicle on days $1-5$ of age. Data are expressed as means \pm SEM (ten animals per group). $* P \leqslant 0.05$ and ${ }^{* *} P \leqslant 0.01$ versus vehicle-treated rats (ANOVA followed by Tukey's test).

day $\left.^{-1}\right)$. Serum $\mathrm{LH}$ and FSH concentrations decreased on the same day (Table 1).

Expt 3. Injection of raloxifene into neonatal rats permanently altered vaginal cyclicity and increased the number of cornified cells in vaginal smears (Table 2).

In adulthood, rats treated neonatally with 100, 250 or $500 \mu \mathrm{g}$ raloxifene day ${ }^{-1}$ showed a significant reduction in body weight and ovarian mass (Fig. 3a,b), whereas uterine mass decreased only in those animals injected with $500 \mu \mathrm{g}$ raloxifene day ${ }^{-1}$ (Fig. 3c). Serum LH and FSH concentrations remained unchanged in adult females treated neonatally with different doses of raloxifene (Fig. 3e), whereas an increase in prolactin was detected in females treated with doses of 250 and $500 \mu$ g raloxifene day ${ }^{-1}$ (Fig. 3f). 
Table 1. Age, body weight and serum concentrations of $\mathrm{LH}$ and FSH on the day of vaginal opening in rats treated with raloxifene $(100,250$ or $500 \mu$ g per rat per day) or vehicle on days $1-5$ of age

\begin{tabular}{|c|c|c|c|c|}
\hline Treatment & $\begin{array}{l}\text { Age } \\
\text { (days) }\end{array}$ & $\begin{array}{l}\text { Body weight } \\
\text { (g) }\end{array}$ & $\begin{array}{c}\mathrm{LH} \\
\left(\mathrm{ng} \mathrm{m}^{-1}\right)\end{array}$ & $\begin{array}{c}\mathrm{FSH} \\
\left(\mathrm{ng} \mathrm{ml}^{-1}\right)\end{array}$ \\
\hline Vehicle & $35.00 \pm 0.48$ & $110.52 \pm 2.33$ & $1.22 \pm 0.21$ & $10.50 \pm 2.01$ \\
\hline \multicolumn{5}{|c|}{ Raloxifene ( $\mu$ g per rat per day) } \\
\hline 100 & $25.33 \pm 0.37^{*}$ & $60.47 \pm 2.31 *$ & $0.21 \pm 0.02 *$ & $3.81 \pm 0.41^{*}$ \\
\hline 250 & $29.00 \pm 0.50^{*}$ & $68.81 \pm 3.94^{*}$ & $0.17 \pm 0.02 *$ & $5.02 \pm 0.68^{*}$ \\
\hline 500 & $24.91 \pm 0.35^{*}$ & $49.06 \pm 2.28^{*}$ & $0.11 \pm 0.006^{*}$ & $4.33 \pm 0.70^{*}$ \\
\hline
\end{tabular}

Data are expressed as means \pm SEM (ten animals per group).

$* P \leqslant 0.01$ versus vehicle (ANOVA followed by Tukey's test).

Table 2. Percentage of constant vaginal oestrus (CVO) and fertility in 90-day-old female rats treated with raloxifene $(50,100,250$ or $500 \mu \mathrm{g}$ per rat per day) or vehicle on days $1-5$ of age

\begin{tabular}{lccc}
\hline Treatment & $\begin{array}{c}\text { Number of } \\
\text { rats tested }\end{array}$ & $\begin{array}{c}\text { Percentage of } \\
\text { rats with CVO }\end{array}$ & $\begin{array}{c}\text { Percentage of } \\
\text { fertile rats }\end{array}$ \\
\hline $\begin{array}{l}\text { Vehicle } \\
\text { Raloxifene }(\mu \text { g per rat per day) }\end{array}$ & 11 & 0 & 100 \\
50 & 12 & 41.66 & $\mathrm{ND}$ \\
100 & 10 & 90 & $\mathrm{ND}$ \\
250 & 11 & 100 & 0 \\
500 & 12 & 100 & 0 \\
\hline
\end{tabular}

ND: not determined.

The histology of the ovaries in control rats showed an abundance of developing follicles and several generations of corpora lutea corresponding to those of the current and previous oestrous cycles (Fig. 4a). Animals treated with $50 \mu \mathrm{g}$ raloxifene day ${ }^{-1}$ showed similar morphological features and several generations of corpora lutea were also found, although large atretic follicles were observed occasionally (Fig. 4b). In rats treated with $100 \mu \mathrm{g}$ raloxifene day $^{-1}$, the ovaries were smaller and corpora lutea were scarce. Rats treated with the highest doses of raloxifene (250 or $500 \mu \mathrm{g} \mathrm{day}^{-1}$ ) had small ovaries in which corpora lutea were not detected, but large atretic follicles were abundant (Fig. 4c,d).

Expt 4. In the control females, serum concentrations of $\mathrm{LH}$ increased 14 days after ovariectomy. This increase was significantly reduced in raloxifene-treated females. Administration of $75 \mu \mathrm{g}$ oestradiol benzoate reduced serum LH concentrations on days 15 and 16 after ovariectomy (at 10:00 h), whereas significant increases were observed at $18: 00 \mathrm{~h}$ (positive feedback between oestradiol and LH). Positive feedback was inhibited in the group treated neonatally with $100 \mu \mathrm{g}$ raloxifene and was significantly reduced in the group treated with $50 \mu \mathrm{g}$ raloxifene (Fig. 5).
Expt 5. No pregnancy was detected in raloxifene-treated ( 250 or $500 \mu \mathrm{g}$ per rat per day) females paired for 21 days with control males (Table 2).

\section{Effects of neonatal administration of raloxifene on reproductive function in males}

Expt 6. On day 20, male rats injected neonatally with different doses of raloxifene showed a significant reduction in body weight (Table 3). On day 20, the dose of $500 \mu \mathrm{g}$ day $^{-1}$ induced a significant reduction in testis mass expressed either in absolute $(16.81 \pm 0.75 \mathrm{mg}$ versus $24.03 \pm 0.68$ in controls; $P \leqslant 0.01$ ) or relative values $(52.62 \pm 1.90 \mathrm{mg}$ per $100 \mathrm{~g}$ body weight versus $59.47 \pm 1.83$ in controls; $P \leqslant 0.05$ ), accompanied by an increase in serum $\mathrm{FSH}$ and prolactin concentrations (Fig. 6b,c), whereas LH concentrations were unchanged (Fig. 6a).

Expt 7. In male rats treated neonatally with 250 or $500 \mu \mathrm{g}$ raloxifene day $^{-1}$, balanopreputial separation was significantly delayed, but due to growth retardation it occurred at a lower body weight than in the controls. Serum FSH and LH concentrations at balanopreputial separation were decreased in raloxifene-treated rats (Table 4). 

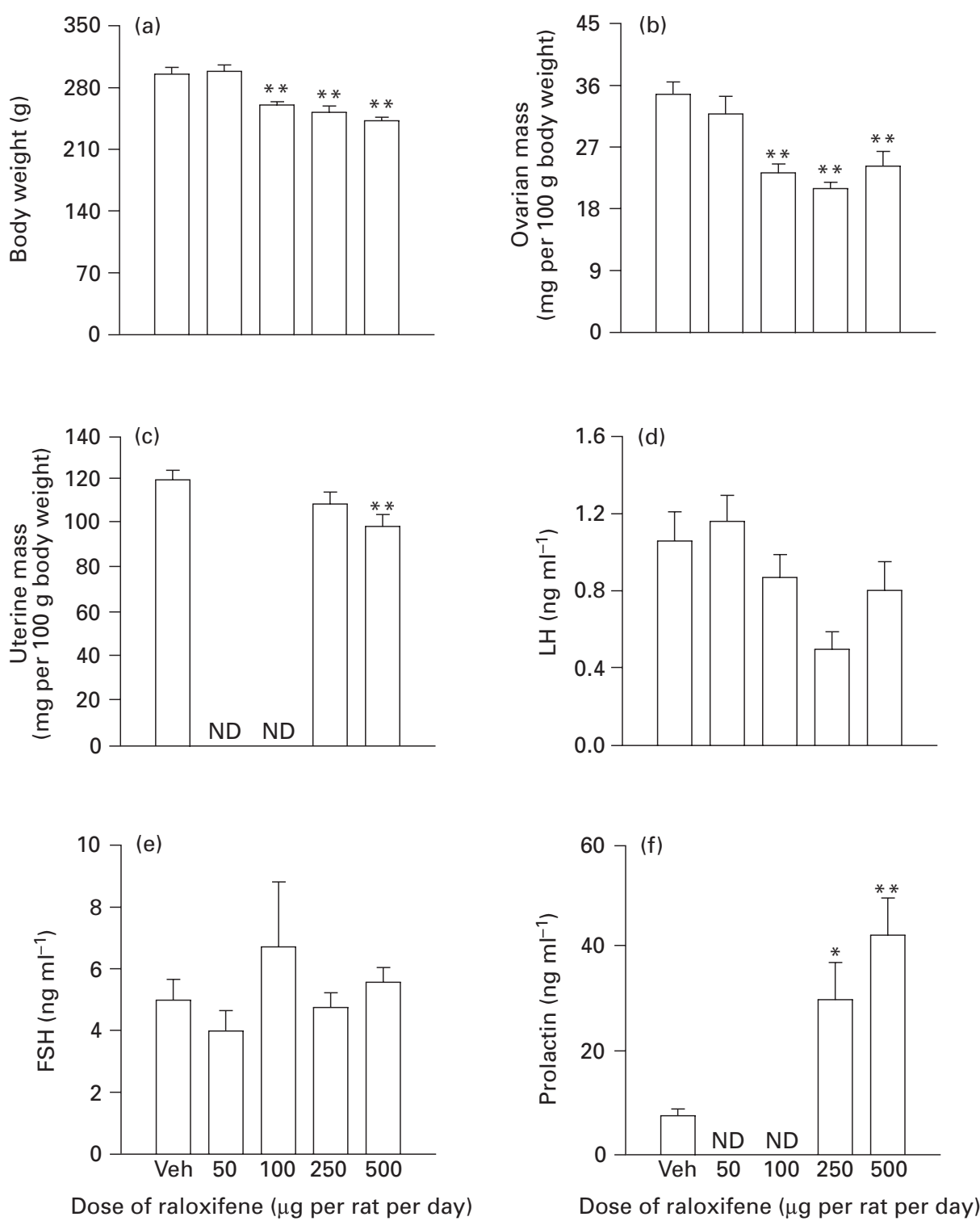

Fig. 3. Body weight, ovarian and uterine masses $(\mathrm{a}, \mathrm{b}, \mathrm{c})$ and serum concentrations of LH (d), FSH (e) and prolactin (f) in adult female rats treated with raloxifene (50, 100, 250 or $500 \mu \mathrm{g}$ per rat per day) or vehicle (Veh) on days $1-5$ of age. Data are expressed as means \pm SEM (ten animals per group). ND = not determined. ${ }^{*} P \leqslant 0.05$ and ${ }^{* *} P \leqslant 0.01$ versus vehicle-treated rats (ANOVA followed by Tukey's test).

Expt 8. Adult male rats treated neonatally with raloxifene ( 250 or $500 \mu$ day $^{-1}$ ) showed a decrease in body weight, whereas testis mass and ventral prostate mass were normal (Table 5). Serum FSH and prolactin concentrations decreased in raloxifene-treated rats (Fig. 7b,c), whereas LH decreased in the raloxifene-treated rats, but the result was not significant (Fig. 7a). The testes of raloxifene-treated rats showed normal morphological features. Spermatogenesis was complete and Leydig cells in the interstitial areas were well differentiated (data not shown).
Expt 9. All control female rats paired with raloxifenetreated males showed normal pregnancies, indicating that the reproductive activity of males was maintained despite neonatal raloxifene treatment.

\section{Discussion}

Results from the present study demonstrate that neonatal administration of raloxifene permanently alters the physiology of the reproductive axis; these effects are more deleterious 

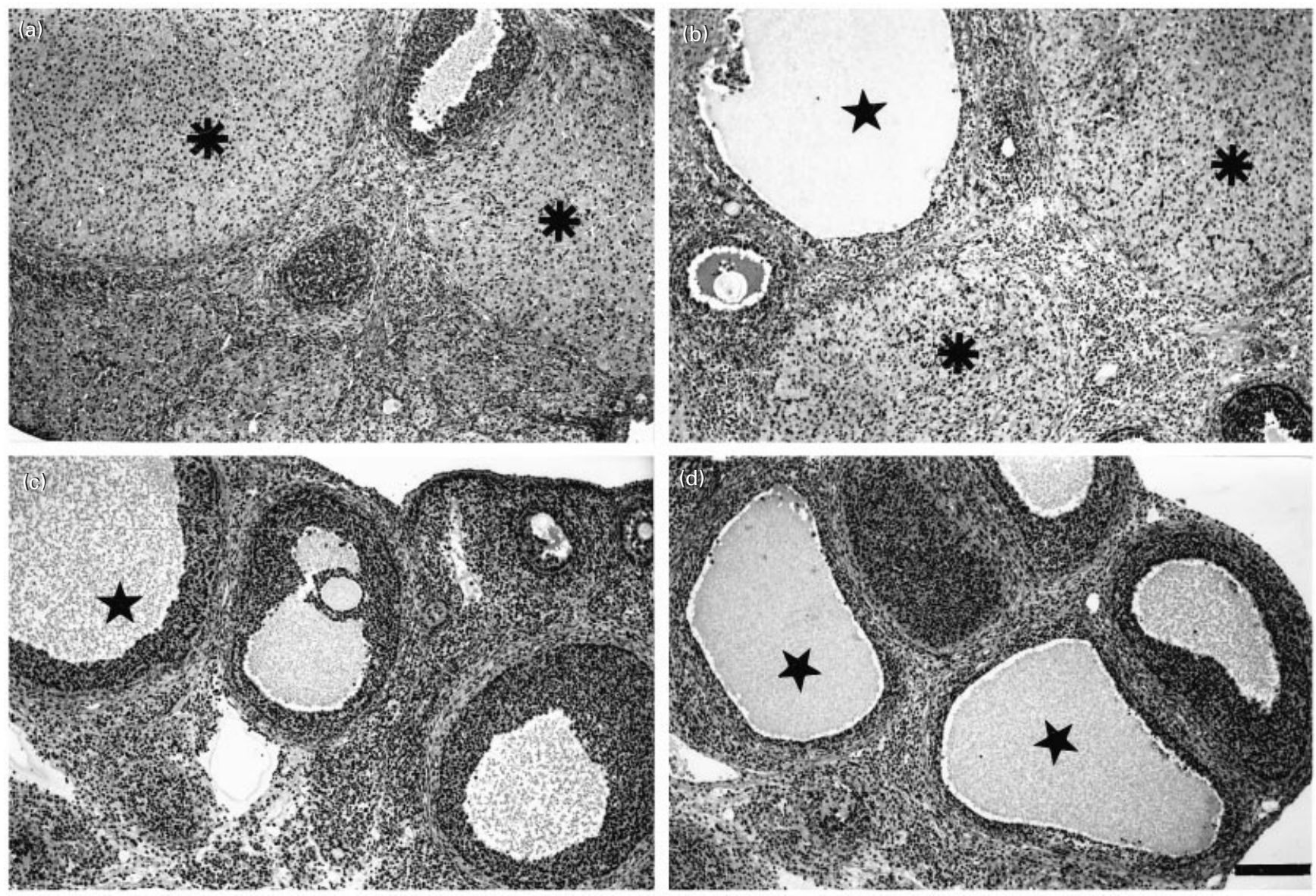

Fig. 4. Micrographs from the ovaries of adult rats treated neonatally with vehicle (a), $50 \mu \mathrm{g}$ (b), $250 \mu \mathrm{g}$ (c) or $500 \mu \mathrm{g}$ (d) of raloxifene. Corpora lutea are indicated by asterisks and large atretic follicles by stars. Scale bar represents $100 \mu \mathrm{m}$.

in females. Such a difference in the impact of raloxifene on reproductive activity in male and female rats is in agreement with the findings of studies in adult animals (Hoyt et al., 1998).

The response to neonatal raloxifene treatment in female rats is characterized by: (i) a decrease in serum gonadotrophin concentration and an increase in prolactin concentrations; (ii) a decrease in body weight, and in ovarian and uterine mass; (iii) advanced vaginal opening; (iv) anovulation with persistent presence of cornified cells in vaginal smears, inhibition of positive feedback between oestradiol and $\mathrm{LH}$, and absence of corpora lutea in ovaries; and (v) infertility. These findings indicate that raloxifene injected on days $1-5$ of age acts as a compound with oestrogenic activity on the hypothalamic-pituitary structures controlling reproductive function. Female rats treated neonatally with oestrogens showed changes almost identical to those induced by raloxifene (Barraclough, 1961; Gorski, 1963; Mallampatti and Johnson, 1973; Aguilar et al., 1979; Pinilla et al., 1993).

Neonatal administration of raloxifene in male rats induced only minor changes in the reproductive axis, and adult testicular histology and fertility were normal. This finding is in agreement with data obtained in mice (Chou et al., 1992). Notably, the reproductive phenotype of male rats injected neonatally with raloxifene is in contrast to the infertility and severe damage to testis structure observed after neonatal administration of oestrogens (Gaytan et al., 1986a,b; Gaytan and Aguilar, 1987). Differences between both treatments may reflect distinct oestrogenic biopotency or may be the consequence of a different kinetic distribution of oestradiol and raloxifene after its administration. Raloxifene has an elimination half-life of 11-27 h (Balfour and Goa, 1998) and is dissolved and injected in saline, whereas oestradiol is administered in oil, thus ensuring prolonged release and action. This difference may indicate that neonatal oestrogenization induced a marked decrease in serum $\mathrm{LH}$ and $\mathrm{FSH}$ concentrations during the prepubertal period (Aguilar et al., 1987), whereas males treated with raloxifene showed normal serum $\mathrm{LH}$ and increased $\mathrm{FSH}$ concentrations on day 20. However, prepubertal male rats treated neonatally with raloxifene showed four characteristics 


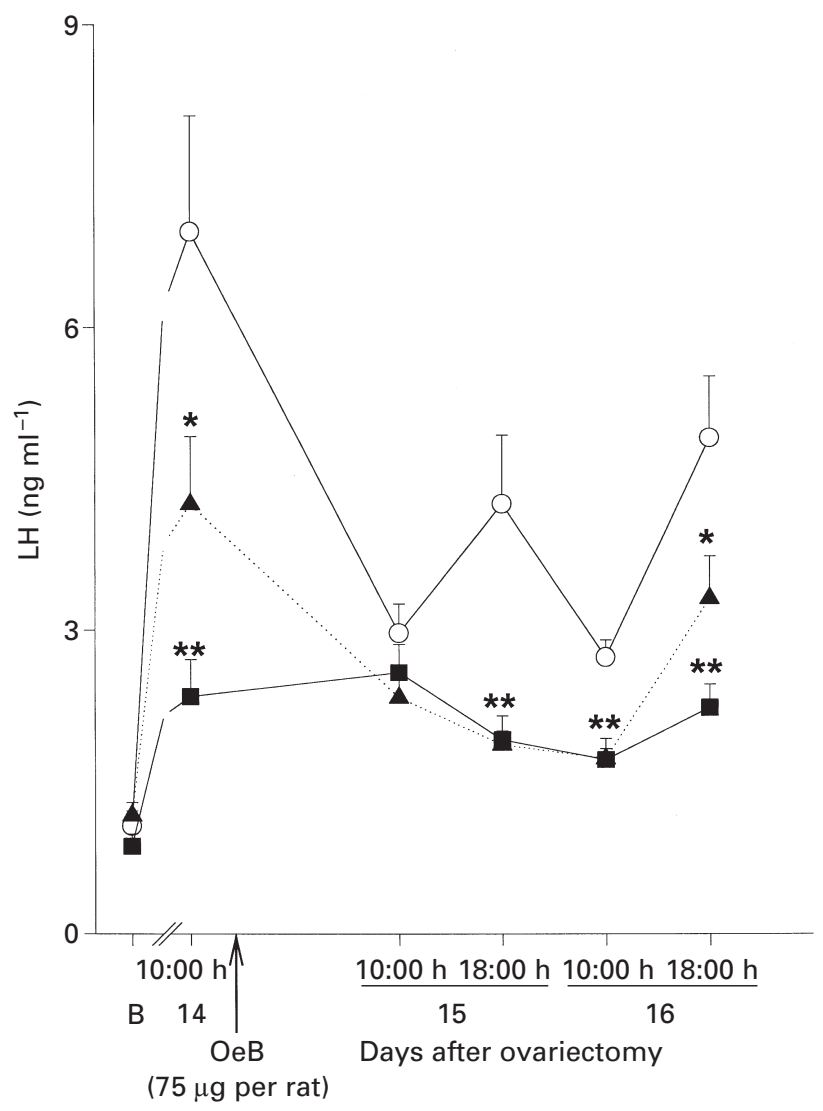

Fig. 5. Serum concentrations of $\mathrm{LH}$ in adult female rats treated with raloxifene (50 $(\boldsymbol{\Delta})$ or $100(\boldsymbol{\square}) \mu \mathrm{g}$ per rat per day) or vehicle $(\bigcirc)$ on days 1-5 of age. Blood samples (B) were obtained on day 90 (10:00 h), and at different days after ovariectomy (day 14, 10:00 h; days 15 and 16, 10:00 and 18:00 h). Animals were injected on day 14 after ovariectomy with $75 \mu \mathrm{g}$ oestradiol benzoate (OeB) (10:00 h). $* P \leqslant 0.05$ and $* * P \leqslant 0.01$ versus values in vehicletreated rats (ANOVA followed by Tukey's test).

similar to those obtained in neonatal oestrogenized males: (i) delayed balanopreputial separation; (ii) decreased gain in body weight; (iii) testis atrophy; and (iv) hyperprolactinaemia (Bellido et al., 1985; Vaticon et al., 1985; Aguilar et al., 1987).

It is well known that differentiation and proliferation of Sertoli cells occurs during the 2 weeks immediately after birth (Steinberger and Steinberger, 1971; Orth et al., 1988) and is critically dependent on FSH secretion (Orth, 1984). However, neonatal proliferation of Sertoli cells is essential for spermatogenesis and fertility in adulthood (Orth et al., 1988). It is possible that raloxifene induced only a shortterm decrease in FSH secretion in male rats followed by a rebound response with the hypersecretion observed on day 20. This may explain the preserved differentiation and proliferation of Sertoli and germ cells, as well as the normal fertility observed in raloxifene-treated male rats in adulthood.
Table 3. Body weight in 20-day-old male rats treated with raloxifene $(50,100,250$ or $500 \mu \mathrm{g}$ per rat per day) or vehicle on days $1-5$ of age

\begin{tabular}{lc}
\hline Treatment & $\begin{array}{c}\text { Body weight } \\
(\mathrm{g})\end{array}$ \\
\hline $\begin{array}{l}\text { Vehicle } \\
\text { Raloxifene }(\mu \mathrm{g} \text { per rat per day) }\end{array}$ & $39.31 \pm 1.01$ \\
50 & $36.41 \pm 0.68^{*}$ \\
100 & $32.86 \pm 0.44^{* *}$ \\
250 & $33.44 \pm 0.68^{* *}$ \\
500 & $32.40 \pm 0.73^{* *}$ \\
\hline
\end{tabular}

Data are expressed as means \pm SEM (15 animals per group).

$* P \leqslant 0.05$ versus vehicle; ${ }^{* *} P \leqslant 0.01$ versus vehicle (ANOVA followed by Tukey's test).
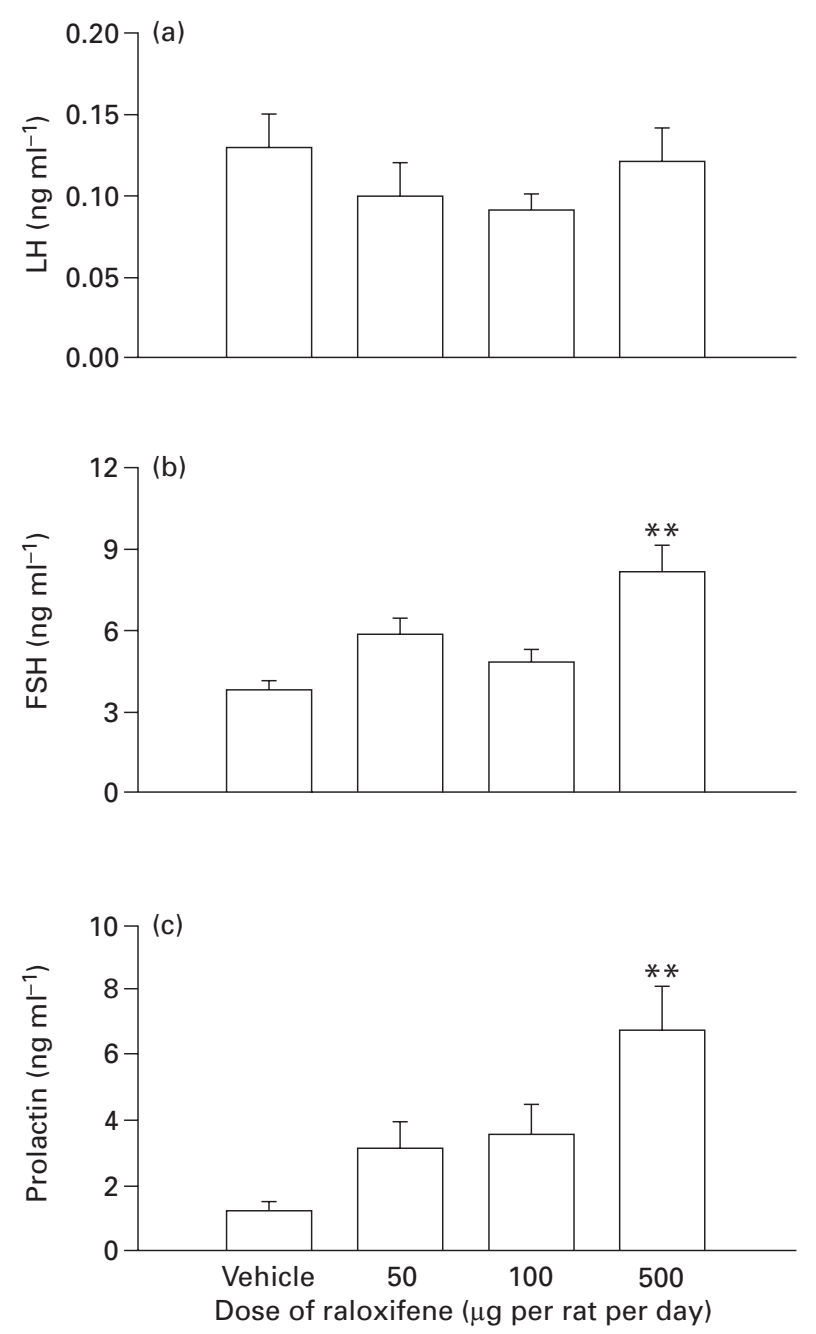

Fig. 6. Serum concentrations of $\mathrm{LH}(\mathrm{a}), \mathrm{FSH}(\mathrm{b})$ and prolactin (c) in 20-day old male rats treated with raloxifene $(50,100$ or $500 \mu \mathrm{g}$ per rat per day) or vehicle on days 1-5 of age. Data are expressed as means \pm SEM (ten animals per group). ${ }^{* *} P \leqslant 0.01$ versus vehicletreated rats (ANOVA followed by Tukey's test). 
Table 4. Age, body weight and serum concentrations of $\mathrm{LH}$ and FSH at balanopreputial separation in rats treated with raloxifene ( 250 or $500 \mu \mathrm{g}$ per rat per day) or vehicle on days $1-5$ of age

\begin{tabular}{lcccr}
\hline Treatment & $\begin{array}{c}\text { Age } \\
\text { (days) }\end{array}$ & $\begin{array}{c}\text { Body weight } \\
(\mathrm{g})\end{array}$ & $\begin{array}{c}\text { LH } \\
\left(\mathrm{ng} \mathrm{m}^{-1}\right)\end{array}$ & \multicolumn{1}{c}{$\begin{array}{c}\text { FSH } \\
\left(\mathrm{ng} \mathrm{m}^{-1}\right)\end{array}$} \\
\hline $\begin{array}{l}\text { Vehicle } \\
\text { Raloxifene }(\mu \mathrm{g} \text { per rat per day) }\end{array}$ & $40.55 \pm 0.33$ & $196.67 \pm 3.26$ & $0.75 \pm 0.12$ & $24.74 \pm 1.99$ \\
$\quad 250$ & $43.66 \pm 0.39^{*}$ & $175.12 \pm 3.73^{*}$ & $0.17 \pm 0.01^{*}$ & $10.82 \pm 1.14^{*}$ \\
500 & $45.72 \pm 0.48^{*}$ & $165.74 \pm 3.38^{*}$ & $0.20 \pm 0.03^{*}$ & $7.73 \pm 0.65^{*}$ \\
\hline
\end{tabular}

Data are expressed as means \pm SEM (ten animals per group).

$* P \leqslant 0.01$ versus vehicle (ANOVA followed by Tukey's test).

Table 5. Body weight and testis and prostate mass in adult male rats treated with raloxifene (250 or $500 \mu \mathrm{g}$ per rat per day) or vehicle on days $1-5$ of age

\begin{tabular}{lccr}
\hline Treatment & $\begin{array}{c}\text { Body weight } \\
(\mathrm{g})\end{array}$ & $\begin{array}{c}\text { Testis mass } \\
(\mathrm{mg})\end{array}$ & $\begin{array}{c}\text { Prostate mass } \\
(\mathrm{mg})\end{array}$ \\
\hline $\begin{array}{l}\text { Vehicle } \\
\text { Raloxifene }(\mu \mathrm{g} \text { per rat per day) }\end{array}$ & $447.0 \pm 6.0$ & $872.30 \pm 22.93$ & $100.00 \pm 6.66$ \\
$\quad$ & & & \\
500 & $368.0 \pm 8.0^{*}$ & $910.00 \pm 20.00$ & $101.62 \pm 7.43$ \\
\hline
\end{tabular}

Data are expressed as means \pm SEM (ten animals per group).

$* P \leqslant 0.01$ versus vehicle (ANOVA followed by Tukey's test).
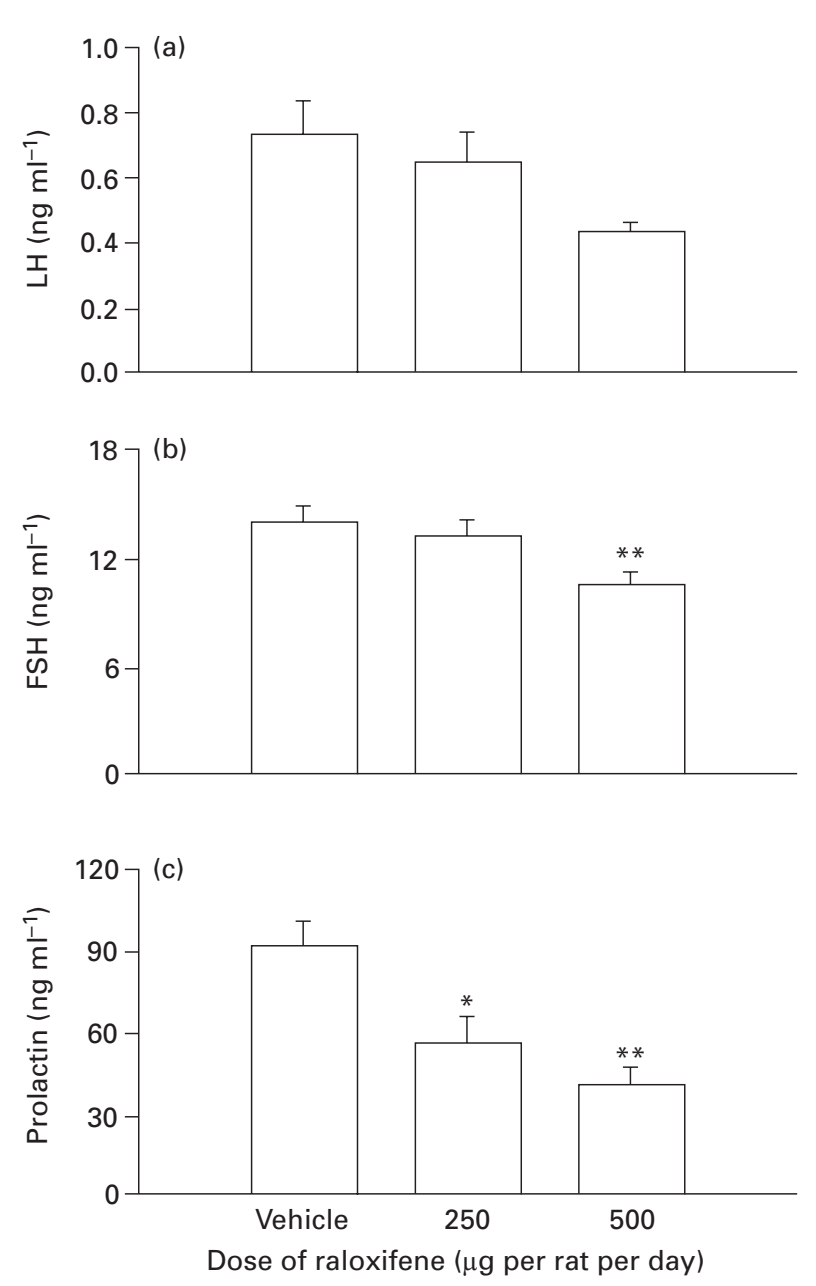

Together, these results highlight the oestrogenic action of raloxifene on the developing central nervous system in rats. This finding opens up the possibility of new uses of raloxifene in the study of the physiology of central nervous system and new preventive actions in raloxifene treatment. Results of international trials indicate that raloxifene is an interesting drug for prevention of osteoporosis in menopausal women, showing very promising efficacy and clinical tolerance (Agnusdei et al., 1999). Recent experiments have indicated that synaptic plasticity of the arcuate nucleus in adult female rats is controlled by oestrogens (Naftolin et al., 1996; Horvath et al., 1997a,b) and progress has been made in understanding the molecular basis of the neuroprotective properties of oestrogens (Garcia Segura et al., 1998; Pike, 1999; Reibel et al., 2000). In this context, promotion of clinical research on the possible disease-modifying or neuroprotective effects of oestrogens in the elderly has been proposed (Schneider and Finch, 1997). These results indicate that, in addition to antioestrogenic activity, raloxifene acts as an oestrogen in the central nervous system and thus support its potential use in these studies.

Nevertheless, further studies of the kinetic characteristics of raloxifene entrance in the central nervous system are necessary to clarify fully the proposed central actions of raloxifene.

Fig. 7. Serum concentrations of $\mathrm{LH}(\mathrm{a}), \mathrm{FSH}(\mathrm{b})$ and prolactin (c) in adult male rats treated with raloxifene $(50,100$ or $500 \mu \mathrm{g}$ per rat per day) or vehicle on days 1-5 of age. Data are expressed as means \pm SEM (ten animals per group). ${ }^{*} P \leqslant 0.05$ and $* * P \leqslant 0.01$ versus vehicle-treated rats (ANOVA followed by Tukey's test). 
The authors are very grateful to R. Campón and I. Aguilar for their technical assistance. This work was supported by grants PM98-0163 (CICYT Spain) and 1FD97-0696-02 (FEDER). The NIH supplied the materials for hormone determinations.

\section{References}

Agnusdei D, Liu-Leage S and Augendre-Ferrante B (1999) Results on international clinical trials with raloxifene Annales $d^{\prime}$ Endocrinology (Paris) 60 242-246

Aguilar E, Fernandez-Galaz C, Tejero A and Vaticon MD (1979) PRL response to $\mathrm{LHRH}$ in neonatally estrogen treated female rats Acta Endocrinologica (Copenhagen) Supplement 2251977

Aguilar E, Bellido C, Aguilar R, Pinilla L, Tejero A and Galaz CF (1987) Mechanisms in the production of prepuberal reproductive defects in neonatal estrogenized male rats Andrología $1922-31$

Balfour JA and Goa KL (1998) Raloxifene Adis New Drug Profile 12 336-341

Barraclough CA (1961) Production of anovulatory sterile rats by single injection of testosterone propionate Endocrinology 68 62-67

Bellido C, Gaytan F, Aguilar R, Pinilla L and Aguilar E (1985) Prepubertal reproductive defects in neonatal estrogenized male rats Biology of Reproduction 33 381-387

Black LJ, Sato M, Rowley ER et al. (1994) Raloxifene (LY 139481) prevents bone loss and reduces serum cholesterol without causing uterine hypertrophy in ovariectomized rats Journal of Clinical Investigation 93 63-93

Buelke-Sam J, Cohen JR, Wierda D, Griffey KI, Fisher LF and Francis PC (1998) The selective estrogen receptor modulator, raloxifene: a segment II/III delivery study in rats Reproductive Toxicology 12 271-288

Chou YC, Iguchi T and Bern HA (1992) Effects of antiestrogens on adult and neonatal mouse reproductive organs Reproductive Toxicology $\mathbf{6}$ 439-446

Ciocca DR and Vargas-Roig LM (1995) Estrogen receptors in human nontarget tissues: biological and clinical implications Endocrine Reviews 16 $35-61$

Clark JH, Schrader WT and O'Malley BW (1992) Mechanisms of action of steroid hormones. In Textbook of Endocrinology pp 35-90 Eds JD Wilson and DW Foster. WB Saunders, New York

Delmas PD, Bfarnason NH, Mitlak BH, Ravoux AC, Shah AS, Huster WJ, Draper MW and Christiansen C (1997) Effects of Raloxifene on bone mineral density, serum cholesterol concentration and uterine endometrium in postmenopausal woman New England Journal of Medicine 337 1641-1647

Dhar JD and Setty BS (1976) Epididymal response to exogenous testosterone in rats sterilized neonatally by estrogen Endokrinologie $\mathbf{6 8}$ 14-41

Draper MW, Flowers DE, Neild JA, Huster WI and Zerbe RL (1995) Antiestrogenic properties of raloxifene Pharmacology 50 209-217

Farhat MY, Javigne MC and Ramwell PW (1996) The vascular protective effects of estrogen FASEB Journal 10 615-624

Fuchs-Young D, Glasebrook AL, Short LL, Draper MW, Rippy MK, Cole HW, Magee DE, Termine JD and Bryant HU (1995) Raloxifene is a tissue-selective agonist/antagonist that functions through the estrogen receptor Annals of New York Academy of Sciences 761 355-360

Garcia Segura LM, Cardona-Gomez P, Naftolin F and Chowen JA (1998) Estradiol upregulates $\mathrm{BCl}-2$ expression in adult brain neurons Neuroreport 9 593-597

Gaytan F and Aguilar E (1987) Qualitative analysis of Sertoli cells in neonatally oestrogen-treated rats Journal of Reproduction and Fertility 79 589-598

Gaytan F, Lucena MC, Pinilla L and Paniagua R (1986a) Effects of neonatal estrogenization on germ cell development Zeitschrift für MikroskopischAnatomische Forschung 100 290-300

Gaytan F, Pinilla L, Aguilar R, Lucena MC and Paniagua R (1986b) Effects of neonatal estrogen administration on rat testis development with particular reference to Sertoli cells Journal of Andrology 7 112-121

Glasebrook AL, Phillis DL and Sluka JP (1993) Multiple binding sites for the anti-estrogen raloxifene (LY156758) Journal of Bone Mineral Research 8 (Supplement 1) A607

Gorski RA (1963) Modification of ovulatory mechanisms by postnatal administration of estrogen to the rat American Journal of Physiology 205 842-844

Gorski RA (1990) Sexual differentiation of the brain: comparative aspects. In Control of the Onset of Puberty pp 231-250 Eds ML Grumbach, PC Sizonenko and ML Aubert. Williams \& Wilkins, Baltimore

Goy RW and McEwen BS (1980) Sexual Differentiation of the Brain MIT Press, Cambridge

Harlan RE, Gordon JH and Gorski RA (1979) Sexual differentiation of the brain: implications for neuroscience Reviews in Neuroscience 4 31-71

Horvath TL, Garcia-Segura LM and Naftolin F (1997a) Control of gonadotropin feedback: the possible role of estrogen-induced hypothalamic synaptic plasticity Gynecology and Endocrinology 11 139-143

Horvath TL, Garcia-Segura LM and Naftolin F (1997b) Lack of gonadotropin-positive feedback in the male rat is associated with lack of estrogen-induced synaptic plasticity in the arcuate nucleus Neuroendocrinology 65 136-140

Hoyt JA, Fisher LF, Swisher DK, Byrd RA and Francis PC (1998) The estrogen receptor modulator, raloxifene: reproductive assessments in adult male rats Reproductive Toxicology 12 223-232

Jacobson CD, Csernus VJ, Shryne JE and Gorski RA (1981) The influence of gonadectomy, androgen exposure, or a gonadal graft in the neonatal rat on the volume of the sexually dimorphic nucleus of the preoptic area Journal of Neuroscience 11142-1147

Jansson J and Frohman LA (1987) Differential effects of neonatal and adult androgen exposure on the growth hormone secretory pattern in male rats Endocrinology $\mathbf{1 2 0} 1551-1557$

Jean-Faucher $\mathbf{C H}$, Berger $\mathbf{M}$, Turckheim $\mathrm{MD}$, Veyssiere $\mathbf{G}$ and Jean $\mathbf{C L}$ (1985) Permanent changes in the functional development of accessory sex organ and infertility in male mice after neonatal exposure to cyproterone acetate Journal of Endocrinology 104 113-120

Johnson LM and Gay VL (1983) Influence of perinatal androgenization on the castration response of adult rats Biology of Reproduction 29 819-823

Mallampatti RS and Johnson DC (1973) Serum and pituitary prolactin, LH and $\mathrm{FSH}$ in androgenized female and normal rats treated with various doses of estradiol benzoate Neuroendocrinology 11 46-56

Naftolin F, Mor G, Horvath TL, Luquin S, Fajer AB, Kohen F and GarciaSegura LM (1996) Synaptic remodelling in the arcuate nucleus during the estrous cycle is induced by estrogen and precedes the preovulatory gonadotropin surge Endocrinology 137 5576-5580

Neubauer BL, Best KL, Clemens JA et al. (1993) Endocrine and antiprostatic effects of raloxifene (LY 156758) in male rat Prostate 23 245-262

Orth JM (1984) The role of follicle-stimulating hormone in controlling Sertoli cell proliferation in testes of fetal rats Endocrinology $\mathbf{1 1 5}$ 1248-1255

Orth JM, Gunsalus GL and Lamperti AA (1988) Evidence from Sertoli celldepleted rats indicates that spermatid numbers in adult depends on numbers of Sertoli cells produced during perinatal development Endocrinology 122 787-794

Pike CJ (1999) Estrogen modulates neuronal Bcl-xL expression and betaamyloid-induced apoptosis: relevance to Alzheimer's disease Journal of Neurochemistry 72 1552-1563

Pinilla L, Trimiño E, Garnelo P, Bellido C, Aguilar R, Gaytan F and Aguilar E (1993) Changes in pituitary secretion during the early postnatal period and anovulatory syndrome induced by neonatal oestrogen or androgen in rats Journal of Reproduction and Fertility 97 13-20

Pozzo-Miller LD and Aoki A (1991) Stereological analysis of the hypothalamic ventromedial nucleus. II. Hormone-induced changes in the synaptogenic pattern Brain Research Developmental Brain Research 61 189-196

Reibel S, Andre V, Chassagnon S, Andre G, Marescaux C, Nehlig A and Depaulis A (2000) Neuroprotective effects of chronic estradiol benzoate treatment on hippocampal cell loss induced by status epilepticus in the female rat Neuroscience Letters 281 79-82

Schneider LS and Finch CE (1997) Can estrogens prevent neurodegeneration? Drugs and Aging 11 87-95 
Steinberger A and Steinberger E (1971) Replication pattern of Sertoli cells in maturating rat testis in vivo and in organ culture Biology of Reproduction 4 84-87

Turner RT, Riggs BL and Spelsberg TC (1994) Skeletal effects of estrogens Endocrine Reviews 15 275-300

Vaticon MD, Fernandez-Galaz MC, Tejero A and Aguilar E (1985) Alteration of prolactin control in adult rats treated neonatally with sex steroids Journal of Endocrinology 105 429-433

Wakeling AE, Valcaccia B, Newboult E and Green LR (1984) Nonesteroidal antioestrogens-receptor binding and biological response in rat uterus, rat mammary carcinoma and human breast cancer cells Journal of Steroid Biochemistry 20 111-120

Wall A and Meyerson BJ (1997) Neonatal castration and adult responsiveness to testosterone in male rats: an interstrain comparison Physiology and Behaviour 62 1371-1378

Whalen RE and Edward DA (1969) Effects of the anti-androgen cyproterone acetate on mating behaviour and seminal vesicle tissue in male rats Endocrinology 84 155-161

Yang NN, Venugopalan M, Hardikar S and Glasebrook A (1996) Identification of an estrogen response element activated by metabolites of $17 \beta$-estradiol and raloxifene Science 273 1222-1225

Received 20 October 2000

First decision 7 December 2000

Accepted 14 February 2001. 